\title{
Az intenzív osztályok 2012. évi átalakításának hatása Magyarországon
}

\author{
Gresz Miklós dr. \\ Állami Egészségügyi Ellátó Központ, Budapest
}

\begin{abstract}
Bevezetés: Magyarországon 2012-ben átalakításra került az intenzív osztályok hálózata. Elkülönítették a multidiszciplináris osztályokat az őrző, megfigyelő jellegủ osztályoktól. Célkitüzés: A szerző elemezte a megmaradó intenzív osztályok egyes mutatóit. Módszer: Az Országos Egészségbiztositási Pénztár adatbázisában a 2000-2015-ben jelentett adatokat vizsgálta a szerző. Eredmények: Az átalakításnak köszönhetően 20\%-kal csökkent az intenzív osztályok és 10\%-kal az intenzív ágyak száma. Ennek következtében mind az esetösszetételi mutató, mind a lélegeztetett napok aránya számottevő́en emelkedett. Az átalakítás következtében a közvetlenül az intenzív osztályokról hazaengedett betegek aránya jelentősen csökkent a 2000. évi 12\%-ról 3\%-ra. A napi ágykihasználtság az átalakítást követóen alapvetően nem változott, és a továbbiakban is minden naptári napon $80 \%$ alatt maradt. A BNO vezető I és J csoportok mellett a fődiagnózisok között a sine morbo (U9990) diagnózisarány a változás előtti $0,7 \%$-ról 0,2\%-ra csökkent. Ugyanígy a csak tüneteket leíró R csoport aránya 1,7\%-ról 1,1\%-ra csökkent. A beavatkozások között a folyadékelektrolit zavar és a légzésmonitorozás száma ezzel szemben jelentős, több mint kétszeres emelkedést mutatott. Köpetkeztetések: Az adatok fényében látható, hogy az átalakítás elérte a célját. Az intenzív osztályok szakmai munkája jelentősen javult a betegellátás zavartalansága mellett. A továbbiakban javasolt az egyes osztályok hasonló szempontok alapján történő elemzése, és az átalakítás következetes továbbvitele. Orv. Hetil., 2016, 157(44), 1757-1761.
\end{abstract}

Kulcsszavak: intenzív osztály, kihasználtság, átalakítás, szakmai munka

\section{Impact of reorganization of the Hungarian system of intensive care units in 2012}

Introduction: In 2012, the Hungarian system of intensive care units was reorganized. During this process, multidisciplinary units were separated from observation units. Aim: The author analysed certain indicators of the remaining intensive care units. Method: The study was based on reports of National Health Insurance Fund between 2000 and 2015. Results: After reorganization the number of the multidisciplinary intensive care units decreased by $20 \%$ and the number of beds decreased by $10 \%$. Due to the reorganization, both the case-mix index and the days of mechanical ventilation increased significantly in the multidisciplinary intensive care units. In $2000,12 \%$ of the patients were discharged directly from the intensive care units to home, but by 2014 , this figure decreased to $3 \%$. The bed-occupancy rate of the intensive care units did not change fundamentally and it was under $80 \%$ in each calendar day. In addition to the ICD leading groups I and J, the rate of "Sine morbo" (U9990) diagnosis decreased from $0.7 \%$ to $0.2 \%$. Similarly, the ratio of R group which describes only symptoms decreased from $1.7 \%$ to $1.1 \%$. In contrast, between the interventions the number of fluid and electrolyte imbalances and respiratory monitoring showed more than twofold increase. Conclusions: These results suggest that the reorganization was effective. The activity of the intensive care units has improved significantly, without disturbing patient care. The author suggests further analysis on the basis of the same criteria for other departments and the consistent continuation of the reorganization process.

Keywords: ICU, bed occupancy rate, reorganization, professional work

Gresz, M. [Impact of reorganization of the Hungarian system of intensive care units in 2012]. Orv. Hetil., 2016, $157(44), 1757-1761$.

(Beérkezett: 2016. július 12.; elfogadva: 2016. augusztus 17.) 
A szerző két korábbi tanulmányában elemezte a hazai intenzív osztályok adatait $[1,2]$. Ezekben kimutatta, hogy az intenzív osztályok nagyon alacsony kihasználtsággal múködnek, és a szakmai munkájuk sem felel meg az elvártnak.

A lakosság arányában az intenzív ágyaink száma nemzetközi összehasonlításban nem rossz (1. ábra), Európa középvonalába tartozunk [3], azonban a forgalmi és finanszírozási adatok alapján az osztályok rendkívül eltéró tevékenységeket végeztek. Ezért 2012-ben átalakításra került az intenzív osztályok hálózata. Különválasztották a valódi multidiszciplináris intenzív osztályokat a posztoperatív őrzőktől és a szakmaspecifikus intenzív osztályoktól. Ez utóbbiak megmaradtak, de nem az intenzíves szakma keretein belül, hanem saját szakmájukban (neurológia, kardiológia, sebészet stb.). Ennek az átalakításnak a hatását vizsgálja a szerző az OEP adatbázisában található adatok alapján.

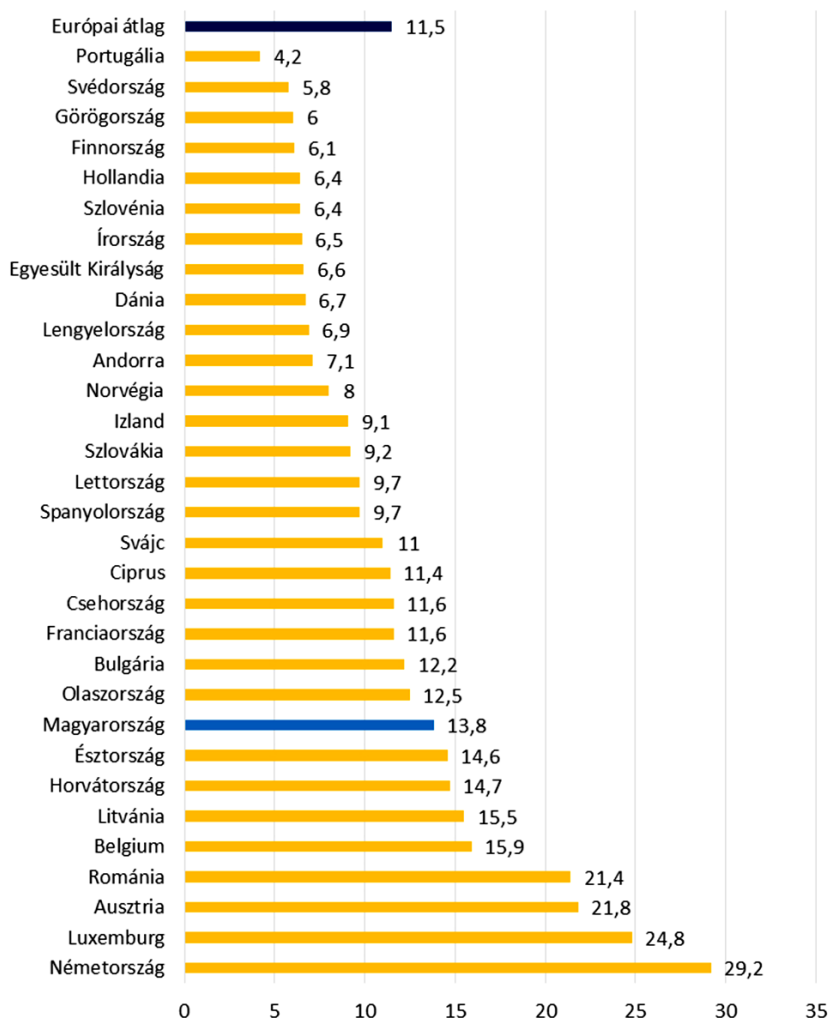

1. ábra $\mid$ A 100 ezer lakosra jutó intenzív ágyak száma Európában, 2012

\section{Módszer}

Lekérdezésre kerültek az OEP adatbázisából az intenzív besorolású osztályok elmúlt 16 évének (2000-2015) adatai. A szerző vizsgálta a strukturális (ágyszám) és a betegellátási (teljesítményjelentési) adatokat.

Az osztályokról jelentett BNO- és OENO-kódok közül elemzésre kerültek a specifikusan az intenzív ellátásra jellemző diagnózisok, eljárások.

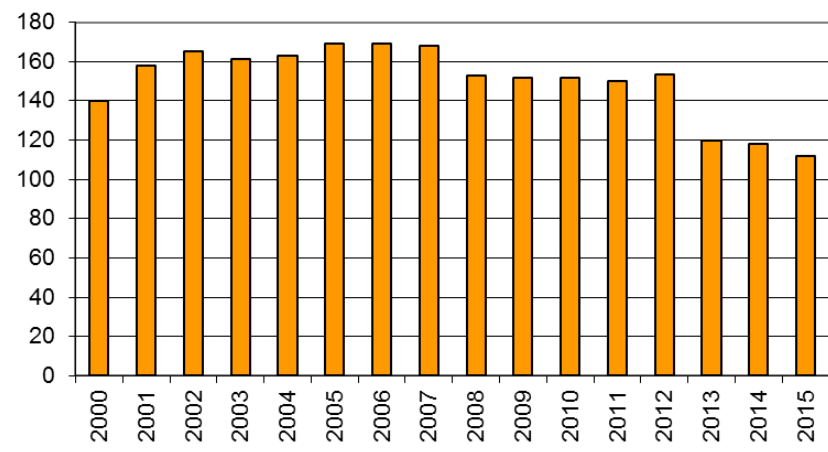

\begin{tabular}{l|l} 
2. ábra & $\begin{array}{l}\text { Az intenzív osztályok száma Magyarországon 2000-2015 kö- } \\
\text { zött }\end{array}$
\end{tabular}

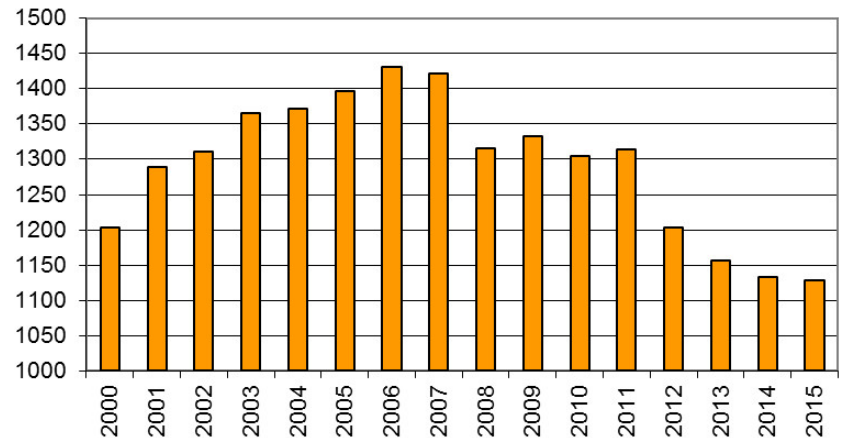

3. ábra | Az intenzív ágyak száma Magyarországon 2000-2015 között

\section{Eredmények}

2012-ben 20\%-kal csökkent az intenzív osztályok és 10\%-kal az intenzív ágyak száma (2. és 3. ábra). Miután az átalakítás augusztus 1 -jén lépett hatályba, az összesített éves adatok csupán 2013-ban mutatnak lényeges eltérést. Míg a változás előtt több mint 150 intenzív osztály volt az országban, 2013-ra a számuk 120 lett.

Az intenzív ágyak számában is jelentős csökkenés észlelhető. Az átalakítást megelőző 1300 feletti ágyszám 1130-ra módosult.

A jelentős ágyszámcsökkenéssel párhuzamosan a súlyos betegek ( 5 feletti súlyszámú HBCs-elszámolások) aránya emelkedett. Ahogyan a 4. ábrán látható, az elmúlt évtizedben folyamatosan több lett az 5 feletti súly-

$60 \%$

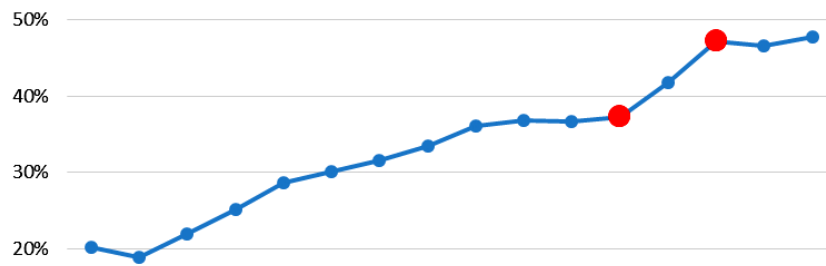

$10 \%$

$0 \%$

2000200120022003200420052006200720082009201020112012201320142015

4. ábra $\quad$ Az 5 feletti súlyszámú esetek aránya az összes esetből 
számú esetek száma, 2011-hez képest 2013-ra jelentős (10\%-os) ugrás látható. Ezen belül a 10 feletti súlyszámú ellátások aránya a 2010. évi 22,6\%-ról 2015-re 30,3\%-ra változott.

Ennek következtében mind az esetösszetételi mutató (CMI), mind a lélegeztetett napok aránya számottevően emelkedett. Ahogyan az 5. ábrán látható, 2008-2011 között a CMI 7,38-7,39 körül stagnált, majd 2013-ban $8,75,2015$-ben 9,1 lett.

A lélegeztetett napok aránya (ami az intenzív ellátás meghatározó része) az átalakítást követően 9-10\%-os emelkedést mutat (6. ábra).

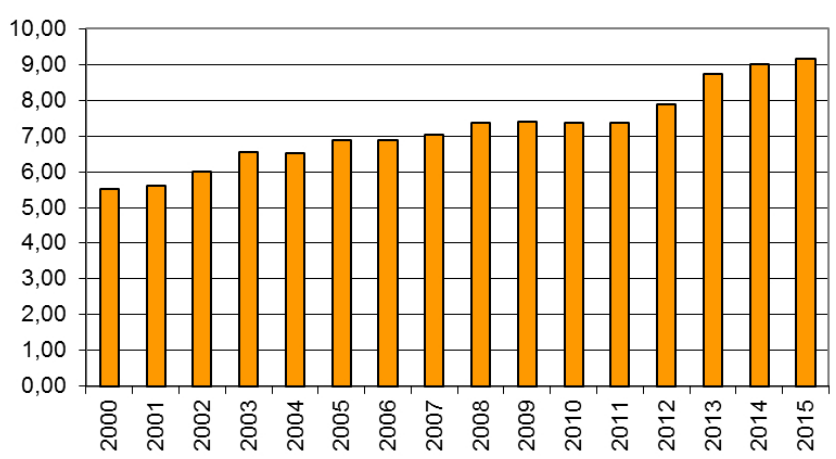

5. ábra $\quad$ Az intenzív osztályok CMI-változása

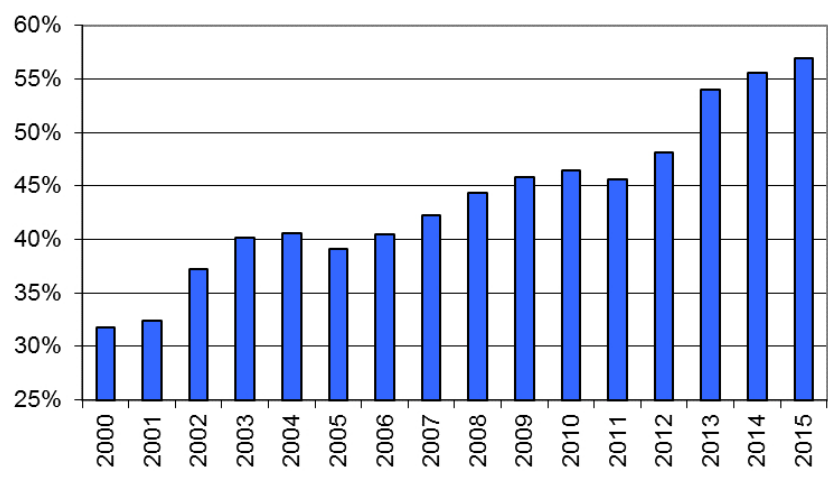

6. ábra $\mid$ A lélegeztetett napok aránya az intenzív osztályokon

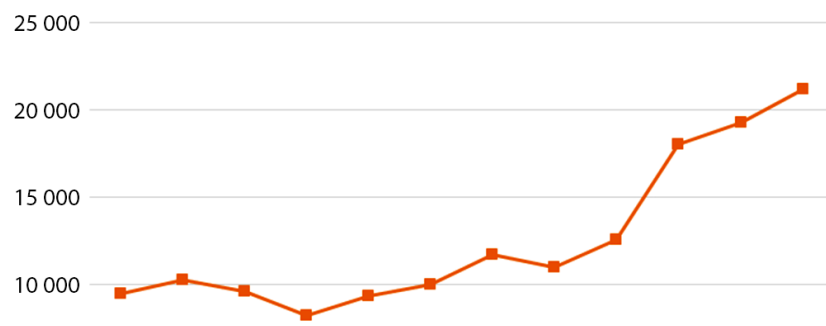

5000

0

7. ábra |A „légzésmonitorozás” beavatkozások számának alakulása
A beavatkozások között - különösen az intenzív osztályokra jellemző beavatkozások vizsgálata során - az látható, hogy a beteg állapotának monitorozására szolgáló eljárások száma jelentősen nőtt. Például a folyadék-elektrolit zavar (89030) vagy a légzésmonitorozás (89300) száma nagymértékú, több mint kétszeres emelkedést mutat (7. és 8. ábra). Mindezek együttesen azt igazolják, hogy az intenzív besorolású osztályokon a szakmai munka színvonala javult, több súlyos beteg kerül ellátásra.

A jelentett adatok azt mutatják, hogy a betegek egy részét közvetlenül az intenzív osztályokról engedik haza. Ez a szerző véleménye szerint felesleges intenzív osztályos tartózkodást jelent. Amennyiben feltételezzük, hogy egy otthonába távozó beteg már legalább 3-4 napja nem szorul intenzív kezelésre, úgy egy beteg 3-4 intenzív osztályos betegnapot vesz feleslegesen igénybe. Az átalakítás előtt a betegek 6-10\%-át küldték haza más osztályra való áthelyezés nélkül (ez 4-8 ezer beteget jelentett évente), majd a változások következtében ezeknek a betegeknek az aránya 2015-re jelentősen csökkent: 3,0\%ra, 1311 betegre (9. ábra).

Bár az ágyszám közel 14\%-kal lett kevesebb, a naptári napi ágykihasználtság nem emelkedett (a változás előtt és után is $65 \%$ körül mozog) (10. ábra). Ez azt mutatja, hogy még mindig nagy számban vannak üres intenzív
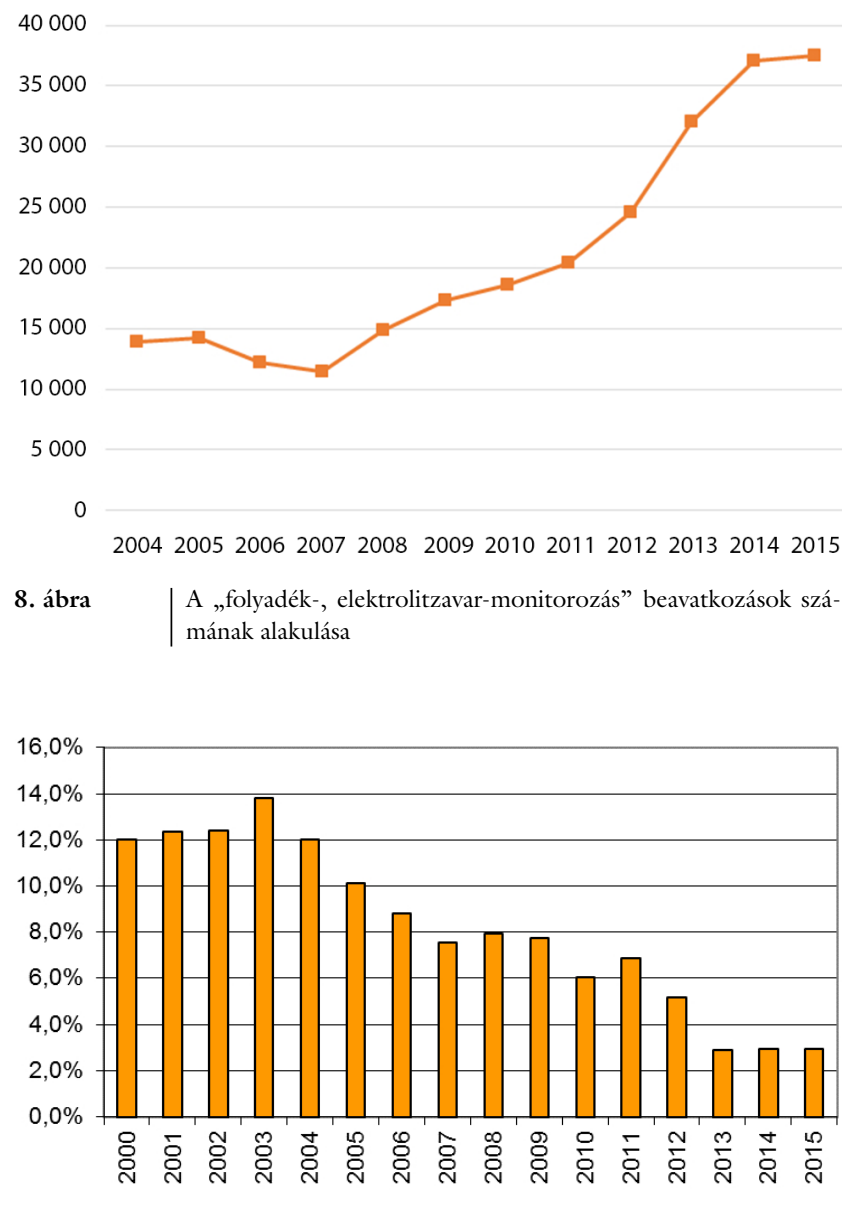

9. ábra $\mid$ Az intenzív osztályról közvetlenül hazabocsátottak aránya 


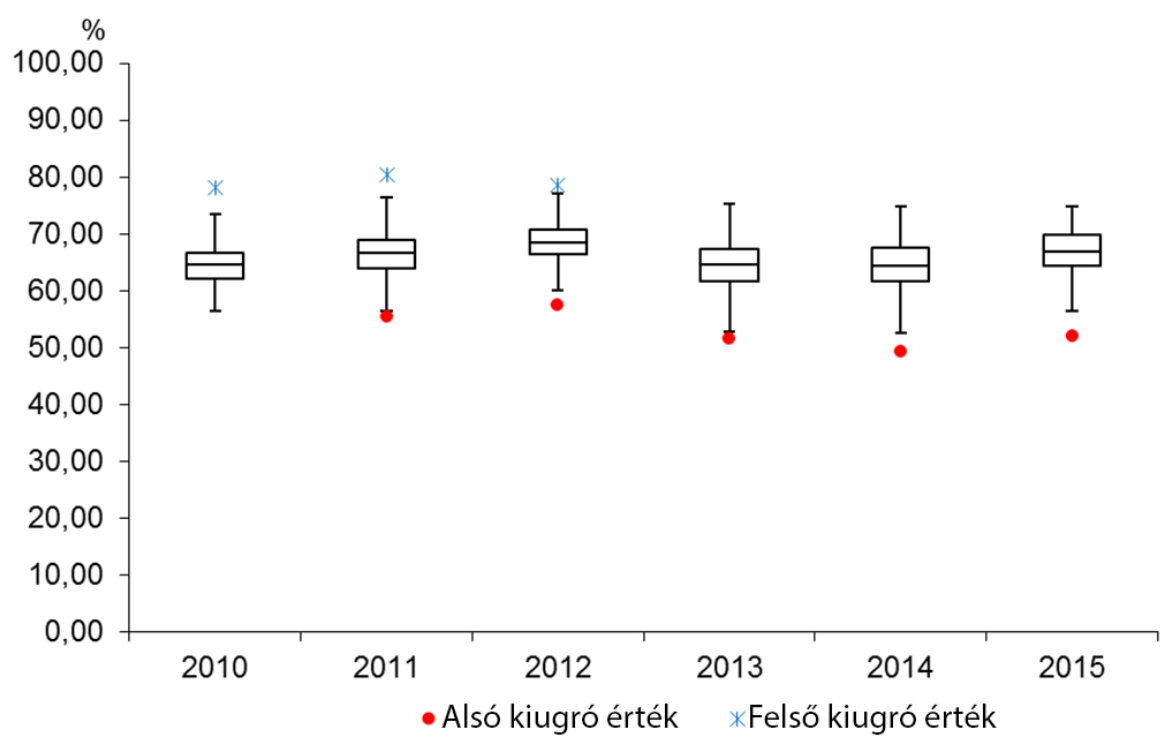

\begin{tabular}{l|l} 
10. ábra & $\begin{array}{l}\text { Az intenzív osztályok napi ágykihasználtságának box-plot ábrá- } \\
\text { zolása }\end{array}$
\end{tabular}

ágyak. Összességében azonban az ágykihasználtság elmarad a kívánatos átlagos 80-85\%-tól [4-5]. Ennek - a nemzetközi adatokkal való összehasonlítás alapján (1. ábra) - lehet az is oka, hogy olyan állapotú betegek, akik más országban (például Németország, ahol a lakosok arányában kétszer ennyi intenzív ágy van) intenzív osztályokra kerülnek, Magyarországon nem lesznek áthelyezve.

A jelentett fódiagnózisok elemzése azt mutatja, hogy a BNO vezető I (keringési rendszer betegségei) és J (légzőrendszer betegségei) csoportok mellett a változtatás előtti 0,7\%-os „sine morbo” (U9990) diagnózisok aránya (ahol úgy fekszik intenzív osztályon a beteg, hogy még iránydiagnózist sem tudtak adni) $0,2 \%$-ra csökkent. Ugyanígy a csak tüneteket leíró R csoport aránya 1,7\%ról 1,1\%-ra csökkent.

\section{Megbeszélés}

Egy intenzív osztályra - megfelelő mưködés esetén - súlyos betegek kerülnek. Emellett egy ilyen osztálynak szervpótló kezeléseket is adni kell tudni, szemben azokkal az osztályokkal, ahol csupán a beteg megfigyelése, fokozott felügyelete történik. Ezért várható, hogy egy valódi intenzív osztályon magas a lélegeztetett és a meghalt betegek aránya. Miután a súlyos betegek magasabb súlyszámú HBCs-t kapnak, várhatóan a CMI-nek is magasnak kell lennie. Az 5 napot meghaladó gépi lélegeztetés súlyszáma 13 feletti, ez jelentősen emelheti az intenzív osztály CMI-jét. Ezért került a dolgozatban vizsgálatra a halálozás és a lélegeztetett napok száma.

A diagnózisok között is jellemzően a súlyos állapotokat jelentő BNO-kódokat várjuk egy ilyen osztályon. A leggyakoribbak a keringési és a légzőrendszer betegségei. Meglepő, ha egy intenzív osztályos tartózkodást kö- vetően érdemi diagnózist nem tudnak megállapítani. Különösen érdekes a „sine morbo” (U9990) diagnózis. Miért is került akkor az intenzívre a beteg?

$\mathrm{Az}$ adatokból látható, hogy elsősorban azok az osztályok, amelyeken közel nulla volt a halálozás, és a lélegeztetett napok száma is elhanyagolható volt, tûntek el az intenzív osztályok köréből.

Egy intenzív osztályos betegnap költsége 2002. évi adatok alapján [6] 35568 Ft (azóta nem készült ilyen vizsgálat). Ennek 32,4\%-a bérköltség és további $8,1 \%$ a klinikai szolgáltatások értéke. A többi a betegtől függő fogyóeszköz, gyógyszer. Ebből fakadóan egy üres ágy költsége 2002-ben 14441 Ft volt.

Figyelembe véve a feleslegesen intenzív osztályon tartott betegek miatt igénybe vett, valamint az évek óta kihasználatlan ágyak fenntartási költségeit [7], elmondhatjuk, hogy jelenleg éves szinten közel 100 ezer ágynapot tartanak fent az intézmények anélkül, hogy az ágyon intenzív ellátásra szoruló beteg feküdne, ami 2002. évi költségeken számolva több mint 1,5 milliárd forint. Amennyiben figyelembe vesszük az inflációt [7], az öszszeg ma már 2,5 milliárd forintnak felel meg. Célszerű lenne ezeket az ágyakat a betegellátás szolgálatába állítani vagy megszüntetni, és a pénzt másra fordítani.

Az adatok alapján elmondható, hogy az intenzív osztályok szakmai tevékenysége átlagosan alacsony szintet mutatott. Ez az átalakítást követően jelentősen változott. Az intenzív ágyak köréből olyan részlegek, osztályok estek ki, amelyek nem végeztek valódi multidiszciplináris intenzív ellátást. Ezzel párhuzamosan a megmaradt osztályok szakmai munkája is javult.

$\mathrm{Az}$ adatok fényében látható, hogy az átalakítás elérte a célját. A továbbiakban javasolt az egyes osztályok hasonló szempontok alapján történő elemzése és az átalakítás következetes továbbvitele. 
Anyagi támogatás: A közlemény megírása, illetve a kapcsolódó kutatómunka anyagi támogatásban nem részesült.

A szerző a cikk végleges változatát elolvasta és jóváhagyta.

Érdekeltségek: A szerzőnek nincsenek érdekeltségei.

\section{Irodalom}

[1] Gresz, M.: Parameters of bed occupancy of intensive care units in Hungary. [A magyarországi intenzív osztályok kihasználtságának néhány paramétere.] Orv. Hetil., 2011, 152(24), 946-950. [Hungarian]

[2] Gresz, M.: Some more parameters of utilization of intensive care units in Hungary. [Az intenzív osztályok kihasználtságának néhány újabb paramétere.] Orv. Hetil., 2011, 152(45), 18131817. [Hungarian]

[3] Rhodes, A., Ferdinande, P., Flaatten, H., et al.: The variability of critical care bed numbers in Europe. Intensive Care Med., 2012, $38(10), 1647-1653$.
[4] Krankenhausplan NRW 2015. https://broschueren.nordrheinwestfalendirekt.de/broschuerenservice/pageflip/mgepa/ krankenhausplan-nrw-2015/1483 https://broschueren.nordrheinwestfalendirekt.de/broschuerenservice/mgepa/krankenhausplan-nrw-2015/1617

[5] Bestandsaufnahme zur Krankenhausplanung und Investitionsfinanzierung in den Bundesländern. http://www.dkgev.de/media/file/11986.DKG_Bestandsaufnahme_KH-Planung_Investitionsfinanzierung_030812.pdf

[6] Csomós, Á.: Cost analysis in intensive care units. [Költségelemzés az intenzív osztályon.] PhD Dissertation. University of Debrecen, 2005. https://dea.lib.unideb.hu/dea/bitstream/ handle $/ 2437 / 2684 /$ Csomos_Akos_ertekezes.pdf?sequence= 1\&isAllowed=y [Hungarian]

[7] Hungarian National Bank benchmark inflation indicators. [A Magyar Nemzeti Bank inflációs alapmutatói.] https://www. mnb.hu/statisztika/statisztikai-adatok-informaciok/adatokidosorok/vi-arak [Hungarian]

(Gresz Miklós dr., Budapest, Fogaskerekü u. 10., 1125 e-mail: gresz.miklos@aeek.hu)

\section{A Kuthy Elek Egészségügyi Intézmény ÁLLÁSPÁLYÁZATA orvos munkakörben}

A tiszafüredi Kuthy Elek Egészségügyi Intézmény 2016-ban az alábbi szakellátásokban megüresedett állások pályázatára kínál lehetőséget.

Az alábbi munkaköröket közremüködői szerződés vagy közalkalmazotti státusz keretében töltheti be a pályázó.

\begin{tabular}{|c|c|c|c|}
\hline $\begin{array}{l}\text { A pályázatot meghirdető } \\
\text { szerv neve, címe }\end{array}$ & Munkakör megnevezése & Pályázati feltételek & Juttatások \\
\hline $\begin{array}{l}\text { Kuthy Elek Eü. Intézmény } \\
5350 \text { Tiszafüred } \\
\text { Nefelejcs út } 4 \text {. }\end{array}$ & $\begin{array}{l}\text { - Gyermekorvos } \\
\text { - Pszichológus } \\
\text { - Nőgyógyász } \\
\text { - Bőrgyógyász } \\
\text { - Szemész szakorvos }\end{array}$ & $\begin{array}{l}\text { - Szakirányú szakképesítés } \\
\text { - Részletes szakmai } \\
\text { önéletrajz } \\
\text { - MOK-tagsági igazolvány } \\
\text { - Működési nyilvántartásba } \\
\text { vétel igazolása } \\
\text { - } 3 \text { hónapnál nem régebbi } \\
\text { erkölcsi bizonyítvány }\end{array}$ & $\begin{array}{l}\text { Juttatások megegyezés } \\
\text { szerint. }\end{array}$ \\
\hline
\end{tabular}

Pályázati határidő: az állások betöltésével véges.

A pályázattal kapcsolatban további információt Habuczki Árpád, az Intézmény gazdasági dolgozója ad. Tel: 06/59/351-244; 06/30/493-7843

Kérjük, hogy a pályázat benyújtásával egy időben személyesen keresse fel az Intézmény orvos igazgatóját, Dr. Hegyi György Pétert. Tel: 06/70/940-8738

A pályázatot az alábbi címre kérjük benyújtani:

Dr. Hegyi György Péter Orvos-igazgató 5350 Tiszafüred, Nefelejcs út 4., illetve a kuthyelek@gmail.com e-mail címre.

Tiszafüred, 2016. október 4. 